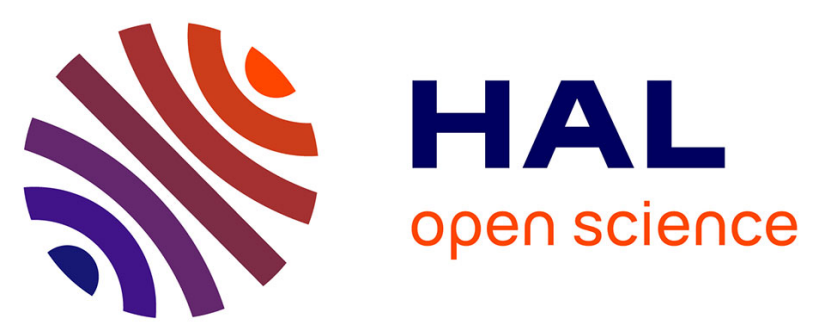

\title{
Contrasting accumulation biokinetics and distribution of 241Am, Co, Cs, Mn and Zn during the whole development time of the eggs of the common cuttlefish, Sepia officinalis
}

Thomas Lacoue-Labarthe, Michel Warnau, François Oberhänsli, Jean-Louis

Teyssié, Paco Bustamante

\section{To cite this version:}

Thomas Lacoue-Labarthe, Michel Warnau, François Oberhänsli, Jean-Louis Teyssié, Paco Bustamante. Contrasting accumulation biokinetics and distribution of $241 \mathrm{Am}, \mathrm{Co}, \mathrm{Cs}, \mathrm{Mn}$ and $\mathrm{Zn}$ during the whole development time of the eggs of the common cuttlefish, Sepia officinalis. Journal of Experimental Marine Biology and Ecology, 2010, 382 (2), pp.131-138. 10.1016/j.jembe.2009.10.008 . hal-00445618

\author{
HAL Id: hal-00445618 \\ https://hal.science/hal-00445618
}

Submitted on 10 Jan 2010

HAL is a multi-disciplinary open access archive for the deposit and dissemination of scientific research documents, whether they are published or not. The documents may come from teaching and research institutions in France or abroad, or from public or private research centers.
L'archive ouverte pluridisciplinaire HAL, est destinée au dépôt et à la diffusion de documents scientifiques de niveau recherche, publiés ou non, émanant des établissements d'enseignement et de recherche français ou étrangers, des laboratoires publics ou privés. 
Contrasting accumulation biokinetics and distribution of ${ }^{241} \mathrm{Am}, \mathrm{Co}, \mathrm{Cs}, \mathrm{Mn}$ and $\mathrm{Zn}$ during the whole development time of the eggs of the common cuttlefish,

\section{Sepia officinalis}

Thomas Lacoue-Labarthe ${ }^{\mathrm{a}}$, Michel Warnau ${ }^{\mathrm{b} \dagger}$, François Oberhänsli ${ }^{\mathrm{b}}$, Jean-Louis Teyssié ${ }^{\mathrm{b}}$, Paco Bustamante $^{\mathrm{a} *}$

a Littoral, Environnement et Sociétés (LIENSs), UMR 6250, CNRS-Université de La Rochelle, 2 rue Olympe de Gouges, F-17042 La Rochelle Cedex 01, France

b International Atomic Energy Agency - Marine Environment Laboratories (IAEA-MEL), 4 Quai Antoine Ier, MC-98000 Principality of Monaco

* Correspondence to: Dr. Paco Bustamante

LIENSs, UMR 6250, CNRS- Université de La Rochelle,

2 rue Olympe de Gouges

F-17042 La Rochelle Cedex 01, France

Phone: $\quad+33546500294$

Fax: $\quad+33546458264$

E-mail: pbustama@univ-lr.fr

† Present address : LIENSs, UMR 6250, CNRS-Université de La Rochelle, 2 rue Olympe de Gouges, F-17042 La Rochelle Cedex 01 (France). E-mail : warnaumichel@yahoo.com 
Abstract: Cuttlefish eggs were exposed to ${ }^{241} \mathrm{Am}, \mathrm{Co}, \mathrm{Cs}, \mathrm{Mn}$ and $\mathrm{Zn}$ for different periods of time during the 50-d of the embryonic development at $17^{\circ} \mathrm{C}$. Exposures were carried out using background dissolved concentrations of the metals, using the corresponding $\gamma$-emitting radiotracers $\left({ }^{241} \mathrm{Am},{ }^{57} \mathrm{Co},{ }^{134} \mathrm{Cs},{ }^{54} \mathrm{Mn}\right.$ and $\left.{ }^{65} \mathrm{Zn}\right)$. Eggs were then placed in non-contaminating conditions. Experiments allowed assessing 1) the uptake and depuration kinetics of the selected elements and 2) their distribution among the different egg compartments (i.e. eggshell, vitellus, peri-vitelline fluid and embryo). ${ }^{241} \mathrm{Am}$, Co and $\mathrm{Zn}$ were accumulated continuously by the eggs all along the development time, whereas $\mathrm{Mn}$ reached saturation after one month of exposure. Interestingly, the uptake kinetics of Cs tightly followed the weight variation of the eggs, mainly because of water influx/outflux. During the first month of the embryonic life, ${ }^{241} \mathrm{Am}, \mathrm{Co}, \mathrm{Cs}, \mathrm{Mn}$ and $\mathrm{Zn}$ remained associated with the eggshell, indicating that the latter acted as an efficient shield against their penetration. Nevertheless, from this time onwards, Co, Cs, Mn and $\mathrm{Zn}$ accumulated more or less efficiently in the embryo according to the following order: $\mathrm{Cs}>\mathrm{Zn}>\mathrm{Mn}>\mathrm{Co} .{ }^{241} \mathrm{Am}$ was the only element tested that did not cross the eggshell all along the exposure time. The depuration kinetics revealed that the retention capacity of the eggs varied during the embryonic life. The contrasting accumulation biokinetics are discussed in terms of chemical and biological processes occurring during the cuttlefish egg development.

Keywords: Metals; Radionuclide; Bioaccumulation; Embryo; Eggshell; Permeability 


\section{Introduction}

The development of nuclear facilities and fallout from nuclear weapon testing resulted in the release of many medium- and long-lived radionuclides into aquatic environments such as ${ }^{241} \mathrm{Am}$, ${ }^{57} \mathrm{Co},{ }^{137} \mathrm{Cs}$ or ${ }^{54} \mathrm{Mn}$ (e.g., Warnau et al., 1999; Ke et al., 2000). Although these radionuclides are generally considered as micropollutants in the oceans, these elements are known to accumulate in marine organisms (e.g., Miramand and Guary, 1981; Warnau et al., 1996a,b, 1999; Baden et al., 1999; Ke et al., 2000; Rodriguez y Baena et al., 2008a). In addition, radionuclides are of specific interest given the ecotoxicological concern regarding their stable isotopes. It is therefore possible to use radiotracers in order to study the bioaccumulation behaviour of the corresponding stable elements that are present in marine waters (e.g., Warnau and Bustamante, 2007).

Along the European Atlantic coasts, the common cuttlefish Sepia officinalis lives offshore during winter and makes long reproductive migrations in spring to mate and to spawn in coastal waters (Boucaud-Camou and Boismery, 1991). The eggs laid in shallow waters are thus subjected to chronic and/or acute exposure to various contaminants such as trace elements which are released from human activities in the coastal marine environment (Danis et al., 2004). When laid, eggs are fixed on hard substrata and exposure to contaminants occur during the whole embryonic development as well as during the juvenile stage until the new cohort leaves the coast towards deeper waters. Certain trace elements are known to be highly toxic to early developmental stages of marine invertebrates (e.g., Calabrese and Nelson, 1974; Warnau et al., 1996c; Coteur et al., 2003). However, very little is known on the related effects of trace elements on cuttlefish development for both acute and chronic exposure and their bioaccumulation is not well documented (see e.g., Lacoue-Labarthe et al. 2008a,b).

Cuttlefish eggs show several specific characteristics including the fact that the telolecithe oocyte is surrounded by a first membrane (i.e. the chorion) derived from the follicular cells in the ovary. At spawning time, it is embedded in mucosubstances produced by the oviducal gland. Once 
released in the mantle cavity, the oocyte is wrapped by ink-stained secretions from the nidamental gland (Jecklin, 1934). These different layers protect the embryo against the surrounding environment, allowing the embryos to remain protected at low tide (Boletzky, 1986). During the early development, the eggshell first hardens at the contact of seawater and then becomes thicker by the polymerization of its components. Then, the egg grows due to entry of water from the seawater to the hypertonic peri-vitelline fluid (De Leersnyder and Lemaire, 1972) and, as the egg swells, the eggshell becomes clearly thinner, being almost transparent at hatching time (Wolf et al., 1985).

Preliminary studies carried out during the last two weeks of the development have shown that cuttlefish eggs did not show the same bioaccumulation efficiencies for different trace elements (i.e. $\mathrm{Ag},{ }^{241} \mathrm{Am}, \mathrm{Cd}, \mathrm{Co}, \mathrm{Cs}, \mathrm{Zn}$ ) (Bustamante et al., 2002, 2004, 2006b). Consistently with these studies, Lacoue-Labarthe et al. (2008a) recently showed that Ag was accumulated efficiently in the embryo only during the last $20 \mathrm{~d}$ of its development. In contrast, the latter authors also reported that $\mathrm{Cd}$ passed slightly across the eggshell, and only during the last few days of the egg development, which highlighted the eggshell time- and element-selective properties. Additionally, the analysis of several metals in cuttlefish eggs collected in the field showed that metal distribution between the eggshell and the embryo was element-dependent (Miramand et al., 2006).

In this context, the aim of this study was to investigate the bioaccumulation of five metals $\left({ }^{241} \mathrm{Am}, \mathrm{Co}, \mathrm{Cs}, \mathrm{Mn}\right.$ and $\mathrm{Zn}$ ) during the whole embryo development time (from spawning (day 0) to hatching (day 50) in cuttlefish eggs chronically exposed to these elements dissolved in seawater. Gamma-emitting radiotracers, ${ }^{241} \mathrm{Am},{ }^{57} \mathrm{Co},{ }^{134} \mathrm{Cs},{ }^{54} \mathrm{Mn}$, and ${ }^{65} \mathrm{Zn}$ were used to investigate the uptake and depuration kinetics at background concentrations (Warnau and Bustamante, 2007). Radiotracer distribution among the eggshell, vitellus, embryo and peri-vitelline fluid was also assessed in order to determine the eggshell permeability changes according to the development stages.

\section{Materials and methods}




\subsection{Organisms, radiotracers and experimental procedure}

Twelve adult cuttlefish were collected by net-fishing off the Principality of Monaco in March and April 2006. Male and female cuttlefish were acclimated and maintained in open-circuit tanks in the IAEA-MEL premises. After mating, the fertilized eggs laid by each single female were immediately separated to optimise their oxygenation. The eggs $(n=310)$ were placed for up to $50 \mathrm{~d}$ in a 70 - $\mathrm{L}$ glass aquarium containing $0.45-\mu \mathrm{m}$ filtered natural seawater (constantly aerated closed circuit; temperature $17 \pm 0.5^{\circ} \mathrm{C} ; 37$ p.s.u.; light/dark cycle $12 \mathrm{~h} / 12 \mathrm{~h}$ ) that was previously spiked with ${ }^{241} \mathrm{Am}\left(0.2 \mathrm{kBq} \mathrm{L}{ }^{-1}\right),{ }^{57} \mathrm{Co}\left(1 \mathrm{kBq} \mathrm{L}{ }^{-1}\right),{ }^{134} \mathrm{Cs}(2 \mathrm{kBq} \mathrm{L}-1),{ }^{54} \mathrm{Mn}(1 \mathrm{kBq} \mathrm{L}-1)$ and ${ }^{65} \mathrm{Zn}(1 \mathrm{kBq} \mathrm{L}-1)$. These activities corresponded to an addition of 7, 10 3 , 256 and $65 \mathrm{pg} \mathrm{L}^{-1}$ stable Co, Cs, Mn and $\mathrm{Zn}$, respectively. The temperature of development considered was chosen to represent the mean seawater temperature in the natural environment during the spawning period off Monaco.

Radiotracers were purchased from Amersham, UK $\left({ }^{241} \mathrm{Am},{ }^{57} \mathrm{Co},{ }^{134} \mathrm{Cs}\right)$ and Isotope Product Laboratory, USA $\left({ }^{54} \mathrm{Mn},{ }^{65} \mathrm{Zn}\right):{ }^{241} \mathrm{Am}$ [as ${ }^{241} \mathrm{AmNO}_{3} ; \mathrm{T}_{1 / 2}=432$ y, ${ }^{57} \mathrm{Co}$ as ${ }^{57} \mathrm{CoCl}_{2} ; \mathrm{T}_{1 / 2}=272 \mathrm{~d}$ ], ${ }^{134} \mathrm{Cs}\left[\right.$ as $\left.{ }^{134} \mathrm{CsCl} ; \mathrm{T}_{1 / 2}=2 \mathrm{y}\right],{ }^{54} \mathrm{Mn}\left[\right.$ as $\left.{ }^{54} \mathrm{MnCl}_{2} ; \mathrm{T}_{1 / 2}=312 \mathrm{~d}\right]$, and ${ }^{65} \mathrm{Zn}$ [as $\left.{ }^{65} \mathrm{ZnCl}_{2} ; \mathrm{T}_{1 / 2}=244 \mathrm{~d}\right]$. Stock solutions were prepared in $0.1 \mathrm{~N}$ nitric acid $\left({ }^{241} \mathrm{Am}\right)$ or in $0.1 \mathrm{~N}$ chloridric acid (other radiotracers) to obtain radioactivities allowing the use of spikes of only a few microliters (typically $5 \mu \mathrm{L}$ ).

Seawater and radiotracer spikes were renewed daily during the first week of the experiment and then every second day to maintain water quality and radiotracer concentrations constant. Due to the lack of the radioisotope, ${ }^{134}$ Cs spikes were stopped after the $43^{\text {th }}$ day of the development time. Radiotracer activities in seawater were checked before and after each water renewal in order to determine the time-integrated radiotracer activities (Rodriguez y Baena et al., 2006a). At different time intervals the radionuclide activities were counted in the same group of 8 tag-identified eggs all along the experiment. At each counting time, the tagged 8 eggs were weighed (Fig. 1) and 4 
additional eggs were counted and dissected to determine the radiotracer distribution between the eggshell and vitellus or (after one month, i.e. when development and size allowed distinguishing and separating the egg compartments) among eggshell (including the chorion), vitellus, embryo and perivitelline fluid.

After 7, 18, 27, and 40 days of exposure, a batch of eggs $(n=70,60,50$ and 40, respectively) was removed from the exposure aquarium and held in a 70-L glass aquarium supplied with clean flowing seawater (open circuit with constant aeration; flux $50 \mathrm{~L} \mathrm{~h}^{-1}$; temperature $17 \pm 0.5^{\circ} \mathrm{C}$; 37 p.s.u.; light/dark cycle 12h/12h). In each batch, 8 eggs were distinctly tagged and counted at different time intervals to establish the depuration kinetics of the radiotracers. At the end of the respective depuration periods (i.e. 43, 22, 13 and 10 days of depuration), the radiotracer distribution among the different egg compartments was determined in 4 eggs. Additionally, groups of 8 unexposed eggs were tagged and placed in each aquarium during depuration experiments to be used as control for possible ${ }^{241} \mathrm{Am},{ }^{57} \mathrm{Co},{ }^{134} \mathrm{Cs},{ }^{54} \mathrm{Mn}$ and ${ }^{65} \mathrm{Zn}$ recycling via seawater.

\subsection{Radioanalyses and data treatment}

Radioactivities were measured using a high-resolution $\gamma$-spectrometry system consisting of four coaxial Germanium (N- or P-type) detectors (EGNC 33-195-R, Canberra ${ }^{\circledR}$ and Eurysis ${ }^{\circledR}$ ) connected to a multi-channel analyzer and a computer equipped with a spectra analysis software (Interwinner $\left.{ }^{\circledR} 6\right)$. The detectors were calibrated with an appropriate standard for each counting geometry used and measurements were corrected for background and physical decay of the radiotracers. Counting times were adapted to obtain relative propagated errors less than 5\% (Rodriguez y Baena et al. 2006b). They ranged from 10 to $30 \mathrm{~min}$ for whole eggs and from $10 \mathrm{~min}$ to $24 \mathrm{~h}$ for the dissected egg compartments. 
Uptake of ${ }^{241} \mathrm{Am},{ }^{57} \mathrm{Co},{ }^{134} \mathrm{Cs},{ }^{54} \mathrm{Mn}$ and ${ }^{65} \mathrm{Zn}$ was expressed as change in load/concentration ratio (LCR, g; ratio between radiotracer content in the egg or egg compartment - Bq- and timeintegrated activity in seawater $-\mathrm{Bq} \mathrm{g}^{-1}$ ) over time, as described in Lacoue-Labarthe et al. (2008a). Although this ratio is rather unusual to express metal accumulation, whole radioactivity content in eggs or in their compartments was preferred over classical expression in terms of concentrations or concentration factors (e.g., Warnau et al., 1996a) in order to overcome the dramatic weight variations of the whole eggs due to water incorporation during the development and that tends to hide the actual accumulation of metals in the whole egg (Lacoue-Labarthe et al., 2008a).

Uptake kinetics were best described by using either a linear equation (Eq. 1), a saturation exponential equation (Eq. 2), or a combined equation (logistic + exponential) (Eq. 3):

$\mathrm{LCR}_{\mathrm{t}}=\mathrm{k}_{\mathrm{u}} \mathrm{t}$

$\mathrm{LCR}_{\mathrm{t}}=\mathrm{LCR}_{\mathrm{ss}}\left(1-\mathrm{e}^{-\mathrm{ke}} \mathrm{t}\right)$

$\operatorname{LCR}_{\mathrm{t}}=\operatorname{LCR}_{\mathrm{ss}}\left(1-\mathrm{e}^{-\mathrm{ke}_{\mathrm{e}} \mathrm{t}}\right) /\left(1+\mathrm{e}^{-\mathrm{ke}_{\mathrm{e}}(\mathrm{t}-\mathrm{I})}\right)$

where $\mathrm{LCR}_{\mathrm{t}}$ and $\mathrm{LCR}_{\mathrm{ss}}(\mathrm{g})$ are the load/concentration ratios at time $\mathrm{t}(\mathrm{d})$ and at steady-state, respectively, $\mathrm{k}_{\mathrm{e}}$ and $\mathrm{k}_{\mathrm{u}}$ are the biological depuration and uptake rate constants $\left(\mathrm{d}^{-1}\right.$ and $\mathrm{g} \mathrm{d}^{-1}$, respectively), respectively (Whicker and Schultz, 1982) and I is a constant.

Radiotracer depuration kinetics were expressed in terms of change in percentage of remaining activity (i.e., radioactivity at time $t$ divided by the initial radioactivity measured in the egg or in the compartment at the beginning of the depuration period $* 100)$ along with time.

The depuration kinetics were best fitted by either a single- (Eq. 4) or a double- (Eq. 5) exponential equation:

$A_{t}=A_{0} e^{-k e t}$

$A_{t}=A_{0 s} e^{-k_{e s} t}+A_{01} e^{-k_{e l} t}$

where $A_{t}$ and $A_{0}$ are the remaining activities (\%) at time $t(d)$ and 0 , respectively, $k_{e}$ is the biological depuration rate constant $\left(\mathrm{d}^{-1}\right)$, and $« \mathrm{~s} »$ and $\ll 1 »$ subscripts refer to the short- and long-lived 
component of the depuration kinetics (Warnau et al., 1996a, 1999). The determination of $\mathrm{k}_{\mathrm{e}}$ allows the calculation of the radiotracer biological half-life (d) according to the relation: $\mathrm{Tb}_{1 / 2}=\ln 2 / \mathrm{k}_{\mathrm{e}}$.

Constants (and their statistics) of the best fitting uptake and depuration kinetic equations (decision based on ANOVA tables for two fitted model objects) were estimated by iterative adjustment of the models using the $n l s$ curve-fitting routine in $\mathrm{R}$ freeware. The level of significance for statistical analyses was always set at $\alpha=0.05$.

\section{Results}

\subsection{Uptake kinetics in the whole eggs}

Figure 2 shows the uptake kinetics of ${ }^{241} \mathrm{Am},{ }^{57} \mathrm{Co},{ }^{54} \mathrm{Mn}$ and ${ }^{65} \mathrm{Zn}$ in the whole eggs. These elements were taken up following two contrasting accumulation patterns. The kinetics of ${ }^{241} \mathrm{Am},{ }^{57} \mathrm{Co}$ and ${ }^{65} \mathrm{Zn}$ were best fitted by a linear model all along the development time with an uptake rate of 28.8 $\pm 0.5,22.2 \pm 0.3$ and $21.9 \pm 0.3 \mathrm{~g} \mathrm{~d}^{-1}$, respectively. Eggs revealed elevated bioaccumulation efficiencies for these three latter elements, with LCR reaching, at the end of the development, $1423 \pm$ $100,1087 \pm 65$ and $1035 \pm 54 \mathrm{~g}$ for ${ }^{241} \mathrm{Am},{ }^{57} \mathrm{Co}$ and ${ }^{65} \mathrm{Zn}$, respectively.

The uptake kinetics of ${ }^{54} \mathrm{Mn}$ followed a saturation exponential model, reaching a steady-state equilibrium $\left(\mathrm{LCR}_{\mathrm{ss}}=131 \pm 3 \mathrm{~g}\right)$ one month after the spawning.

Finally, ${ }^{134} \mathrm{Cs}$ LCR values described as a function of the development time did not follow an usual uptake kinetic model (Figure 3.A.). Although the uptake pattern of ${ }^{134} \mathrm{Cs}$ appeared quite complicated, with a sudden drop in LCR after day 43 induced by the lack of the radiotracer in the water, it actually followed rather tightly the pattern of the egg weight variation shown in Figure 1. This is further corroborated by the highly significant correlation (Pearson test; $\mathrm{p}<0.001$ ) observed 
between ${ }^{134} \mathrm{Cs}$ LCR in the whole egg and the egg wet weight for the whole duration of the development (Fig. 3B). The maximum LCR value reached during the exposure period $(4.4 \pm 0.3 \mathrm{~g}$ at day 43) showed limited uptake capacity of this element compared to the other ones.

\subsection{Uptake kinetics and distribution of the radiotracers in the egg compartments}

Uptake kinetics of ${ }^{241} \mathrm{Am},{ }^{57} \mathrm{Co},{ }^{54} \mathrm{Mn}$ and ${ }^{65} \mathrm{Zn}$ in the eggshell and in the embryo are shown in Figure 4. It is worth noting that the eggshell readily concentrated the four elements according to the same pattern as those described above for the whole egg. In addition, the ${ }^{241} \mathrm{Am},{ }^{57} \mathrm{Co}$, and ${ }^{65} \mathrm{Zn}$ uptake kinetics were characterized by similar LCR reached in eggshell and whole egg at the end of the development $(1277 \pm 117$ vs. $1423 \pm 100 \mathrm{~g}, 1181 \pm 99$ vs. $1087 \pm 65 \mathrm{~g}$ and $1012 \pm 59$ vs. $1035 \pm$ $54 \mathrm{~g}$, respectively). No significant uptake of ${ }^{241} \mathrm{Am}$ was found in the embryo whereas ${ }^{57} \mathrm{Co}$ and ${ }^{65} \mathrm{Zn}$ were concentrated efficiently in this compartment according to a combined (saturation + logistic) model reaching estimated $\mathrm{LCR}_{\mathrm{ss}}$ values of $39 \pm 7$ and $284 \pm 72 \mathrm{~g}$, respectively. A few hours before hatching, the LCR values in the embryo were still 40 and 4 fold lower than in the eggshell for ${ }^{57} \mathrm{Co}$ and ${ }^{65} \mathrm{Zn}$, respectively.

The uptake kinetics of ${ }^{54} \mathrm{Mn}$ in the eggshell followed a saturation exponential model as previously determined for the whole egg, and steady-state equilibrium was reached at day 20. The estimated $\mathrm{LCR}_{\mathrm{ss}}$ in the eggshell was similar to that found in the whole egg (124 \pm 4 vs. $\left.131 \pm 3 \mathrm{~g}\right)$. After one month of development, ${ }^{54} \mathrm{Mn}$ activity started to be detected in the embryo and increased according to a combined (saturation + logistic) model, reaching an $\mathrm{LCR}_{\mathrm{ss}}$ of $8.5 \pm 0.7 \mathrm{~g}$.

The distribution of the radiotracers in the different egg compartments revealed that the highest proportion of ${ }^{241} \mathrm{Am},{ }^{57} \mathrm{Co},{ }^{54} \mathrm{Mn}$ and ${ }^{65} \mathrm{Zn}$ remained associated with the eggshell all along the development duration (Table 1). Nevertheless, at day 50, i.e. a few hours before hatching, ca. 3, 7 and $18 \%$ of ${ }^{57} \mathrm{Co},{ }^{54} \mathrm{Mn}$ and ${ }^{65} \mathrm{Zn}$, respectively, were found in the embryo, showing that (1) an 
effective penetration of these metals occurred across the eggshell and (2) that these elements were subsequently incorporated in the embryo. The proportion of these elements in the peri-vitelline fluid remained low $(\leq 1 \%)$ all along the development. Regarding ${ }^{134} \mathrm{Cs}$, it was slightly detected in the vitellus at day 11 and $33\left(3.8 \pm 1.4\right.$ and $2.3 \pm 0.8 \%$, respectively). At day 33 , the proportion of ${ }^{134} \mathrm{Cs}$ in the peri-vitelline fluid was close to that in the eggshell $(27.2 \pm 7.1 \mathrm{vs.} 19.9 \pm 2.1 \%)$, and at day 50, $39.7 \pm 2.3 \%$ of the ${ }^{134} \mathrm{Cs}$ was associated with the embryo and $12.3 \pm 3.6 \%$ with the peri-vitelline fluid (Table 1).

\subsection{Depuration kinetics of the radiotracers from the whole eggs}

After 7, 18, 27 and $40 \mathrm{~d}$ of exposure period, non-contaminating conditions were restored and depuration kinetics of the five elements were followed until the end of the egg development. Except for eggs placed in depuration conditions following $27 \mathrm{~d}$ of ${ }^{241} \mathrm{Am}$ exposure, ${ }^{241} \mathrm{Am}$ and ${ }^{57} \mathrm{Co}$ depuration kinetics in the whole egg were best fitted using a single exponential model (Table 2). The ${ }^{241}$ Am estimated biological half-life $\left(\mathrm{Tb}_{1 / 2}\right)$ decreased with increasing duration of egg pre-exposure $\left(\mathrm{Tb}_{1 / 2}\right.$ was $57,39,32$ and $18 \mathrm{~d}$ after 7, 18, 27 and $40 \mathrm{~d}$ of exposure, respectively). In contrast, the $\mathrm{Tb}_{1 / 2}$ of ${ }^{57} \mathrm{Co}$ remained similar following a 27 - and 40-d exposure, implying that the strength of the binding sites were not affected during the last $23 \mathrm{~d}$ of the egg development.

After 18, 27 and $40 \mathrm{~d}$ of exposure to ${ }^{54} \mathrm{Mn}$, the depuration kinetics were best described by a double exponential equation indicating that, after two weeks of development, ${ }^{54} \mathrm{Mn}$ was released according to two differently bound pools: a tightly-bound component $\left(87,83\right.$ and $70 \%$ of ${ }^{57}$ Co lost with a $\mathrm{Tb}_{1 / 2}$ of 24,21 and $29 \mathrm{~d}$, respectively) and a weakly-bound one $\left(13,18\right.$ and $30 \%$ of ${ }^{57}$ Co lost with a $\mathrm{Tb}_{1 / 2}$ of ca. $\left.1 \mathrm{~d}\right)$. 
Whether after 7, 17, 27 or $40 \mathrm{~d}$ of exposure, a double exponential equation always best fitted the depuration kinetics of ${ }^{65} \mathrm{Zn}$, with the greatest fraction lost according to a long-lived component (88, 87, 83 and $70 \%$ lost with $\mathrm{Tb}_{\frac{1}{2} \mathrm{of}}$ 123, 56, 46 and $79 \mathrm{~d}$, respectively).

Regarding ${ }^{134} \mathrm{Cs}$, after $7 \mathrm{~d}$ of exposure, the tracer was released in similar proportion according to a short- and a long-lived component $\left(44 \pm 8 \%\right.$ lost with $\mathrm{Tb}_{1 / 2}$ of $0.3 \mathrm{~d} v s .56 \pm 4 \%$ lost with $\mathrm{Tb}_{1 / 2}$ of 44 d). Surprisingly, after $18 \mathrm{~d}$ of exposure, its depuration kinetics was best described by a single exponential equation then, after 27 and $40 \mathrm{~d}$ of exposure, the second depuration component was detected again. This second exponential component concerned 32 and 33\% of the whole-body activity of ${ }^{134} \mathrm{Cs}$ and displayed a stronger retention after one month of development $\left(\mathrm{Tb}_{1 / 2}=98 \mathrm{~d}\right.$ after a 27-d exposure) than $10 \mathrm{~d}$ prior to hatching $\left(\mathrm{Tb}_{\frac{1}{2}}=23 \mathrm{~d}\right.$ after a $40-\mathrm{d}$ exposure).

\section{Discussion}

The cuttlefish egg shows dramatic structural modifications throughout a relative short development time (i.e. $50 \mathrm{~d}$ at $17^{\circ} \mathrm{C}$ ). First, as shown in Figure 1, the egg weight varies greatly, with a factor of 4 between day 11 (when weight is minimum) and the end of the development (when weight is maximum). The organogenesis of the embryo occurs from the spawning time to day 25-28 (Wolf et al., 1985). From this moment onwards, the embryo starts an exponential growth period, which goes along with an increase of the peri-vitelline fluid volume due to water intake. At the same time, the vitellus is absorbed to supply the needs of the embryo growth. Thus, in order to take into account the weight variations due to vitellus reduction, embryo growth and incorporation of water during the development, the metal bioaccumulation was expressed in this study in terms of metal content in the whole egg and its different compartments (eggshell, embryo, vitellus, and peri-vitelline fluid). Such data treatment using organism load/water concentration ratio (LCR) has already proven 
to overcome efficiently the tendency of important weight variation (mainly due to water entry) to hide metal accumulation in cuttlefish eggs (Lacoue-Labarthe et al., 2008a).

During the embryo development, ${ }^{241} \mathrm{Am}, \mathrm{Co}, \mathrm{Cs}, \mathrm{Mn}$ and $\mathrm{Zn}$ were efficiently taken up from seawater by the eggs. LCR determined at the end of the development varied according to the elements with ${ }^{241} \mathrm{Am}>\mathrm{Co} \approx \mathrm{Zn}>\mathrm{Mn}>>\mathrm{Cs}$. This is very different from previous results obtained with the same radiotracers in exposures during the last two weeks of the egg development: concentration factors at steady-state saturation decreased following the order $\mathrm{Zn}>\mathrm{Co}>{ }^{241} \mathrm{Am}>>\mathrm{Cs}$ (Bustamante et al. 2002, 2004, 2006b).

In our study, the five radiotracers showed three different uptake behaviours towards the whole eggs: (i) ${ }^{241} \mathrm{Am}$, Co and $\mathrm{Zn}$ were accumulated following a linear model in the egg all along the development time; (ii) Mn uptake reached a steady-state equilibrium after one month, and (iii) the Cs load was correlated with the egg weight variations. The constant rising accumulation of ${ }^{241} \mathrm{Am}$, Co and $\mathrm{Zn}$ in the whole eggs suggests that their binding sites in/on the eggs were not saturated at the end of the development. In similar conditions, dissolved Ag was also efficiently accumulated in the egg, but with a sudden increase after one month of development when the eggs began to swell (LacoueLabarthe et al. 2008a). In contrast to Ag, it seems that ${ }^{241} \mathrm{Am}$, Co and $\mathrm{Zn}$ uptake capacities of the cuttlefish egg were not affected by the changes in the developmental physiology occurring during the embryo life. In this context, the temperature on which depends the development delay could be a determining factor for ${ }^{241} \mathrm{Am}$, Co and $\mathrm{Zn}$ accumulation in the whole egg (Lacoue-Labarthe et al. submitted).

When considering the different egg compartments, the greatest amount of ${ }^{241} \mathrm{Am}, \mathrm{Co}$ and $\mathrm{Zn}$ taken up remained associated with the eggshell all along the development time. Moreover, the similarity of the uptake kinetics between whole egg and eggshell (i.e., best fitting model and LCR values reached; see Figs 2 and 4) strongly suggests that the mechanisms involved in the uptake of ${ }^{241} \mathrm{Am}, \mathrm{Co}$ and $\mathrm{Zn}$ in the whole egg are those that govern metal bioaccumulation in the eggshell. In 
dogfish, eggs were also found to efficiently accumulate ${ }^{241} \mathrm{Am}, \mathrm{Co}$ and $\mathrm{Zn}$, which was hypothesized to be due to binding to the collagen and glycosaminoglycans of the eggshell (Jeffree et al., 2006). In cephalopods, the nidamental secretions contain high proportion of glycine, threonine, proline and isoleucine (Kimura et al., 2004). It is thus likely that ${ }^{241} \mathrm{Am}$, Co and $\mathrm{Zn}$ could bind to and be retained on these carboxyl-rich groups of the eggshell mucopolysaccharides (Miramand et al., 1989; Passow, 2002; Rodriguez y Baena et al., 2006a, 2008b). Zn is well-known for its affinity for the sulfhydryl groups (e.g., Wedemeyer, 1968; Temara et al., 1997) and might bind to those that occur in the mucine-rich egg surface layers (Boletzky, 1998; Kimura et al., 2004). Interestingly, Zn was exclusively detected in the cuttlefish eggshell after 7 and $17 \mathrm{~d}$ of exposure and a substantial fraction of the metal (i.e. 59 to $76 \%$ ) was strongly retained, with $\mathrm{Tb}_{1 / 2}$ of 123 and $56 \mathrm{~d}$, respectively, and could thus be bound to cation-retaining sulfhydryl groups. Therefore, the eggshell would act as a protective barrier limiting/hindering the incorporation of waterborne metals into the embryo, as previously suggested for other metals and radionuclides (Miramand et al., 2006; Villanueva and Bustamante, 2006; Lacoue-Labarthe et al., 2008a).

The distribution of ${ }^{241} \mathrm{Am}$, Co and $\mathrm{Zn}$ among the different egg compartments indicated that their accumulation in the embryo varied widely according to the radiotracer. Indeed, ${ }^{241} \mathrm{Am}$ did not pass through the eggshell all along the development time, whereas Co and $\mathrm{Zn}$ were increasingly detected in the embryo during the last $20 \mathrm{~d}$. This indicates that the protective role of the eggshell may be limited to some extent for Co and $\mathrm{Zn}$.

The biological half-life of ${ }^{241} \mathrm{Am}$ associated with the eggshell decreased with increasing duration of the egg pre-exposure to the radionuclide, allowing the assumption that ${ }^{241} \mathrm{Am}$ retention capacity decreased as the eggshell undergoes structural and chemical modifications throughout the development, such as the polymerization of its components and the decrease in its thickness (Boletzky, 1998). 
The Zn uptake kinetics in the eggshell and embryo showed that this element began to be incorporated in the embryo after one month of development and that embryo was containing $20 \%$ of the total egg burden of $\mathrm{Zn}$ a few hours before hatching. This accumulation of $\mathrm{Zn}$ in the embryo during the last $20 \mathrm{~d}$ of the development period was also previously suggested for $\mathrm{Cu}$ (Paulij et al., 1990) and is most probably related to the fact that both metals are essential elements which are needed for the synthesis of numerous cell constituents such as proteins and enzymes (e.g., Vallee and Auld, 1990). The important metabolic needs in $\mathrm{Zn}$ during the early stages of cuttlefish are well supported by other studies (e.g., Miramand et al., 2006, Villanueva and Bustamante 2006). Indeed, $\mathrm{Zn}$ is maternally transferred quite efficiently from the female cuttlefish to its offspring (LacoueLabarthe et al., 2008b), where it is incorporated in the vitellus during oogenesis (Falchuk and Montorzi, 2001). After hatching, young cuttlefish continue to bioaccumulate $\mathrm{Zn}$ very efficiently both from seawater and food (Bustamante et al., 2002; Miramand et al., 2006). This suggests that the $\mathrm{Zn}$ available before hatching (which is limited by the permeability of the eggshell) is just sufficient for the embryo development needs. It is therefore not surprising that the $\mathrm{Zn}$ accumulated in the embryo was strongly retained during the last days of development $\left(\mathrm{T}_{\mathrm{b}^{1 / 2}}\right.$ of ca. $80 \mathrm{~d}$ after $40 \mathrm{~d}$ of exposure).

Co, which is also an essential element known to be stored in branchial hearts and digestive gland of octopus and cuttlefish following seawater exposure (Nakahara et al., 1979; Bustamante et al., 2004) also passed through the eggshell. However, Co penetration was limited compared to $\mathrm{Zn:}$ only $3 \%$ of the total Co amount taken up reached the embryo a few hours before hatching. In depuration conditions, the biological half-life of Co decreased after a 27-d and a 40-d exposure period, suggesting that the Co binding strength to the eggshell decreased once the embryo growth period started. After $40 \mathrm{~d}$ of exposure, Co was lost according to a 2-component exponential equation, which suggests the involvement of high and low affinity-binding sites $\left(\mathrm{T}_{\mathrm{b}^{1 / 2}}=50 \mathrm{vs} .1 .7 \mathrm{~d}\right)$, coinciding with its occurrence in both the eggshell and the embryo. 
Overall, ${ }^{241} \mathrm{Am}, \mathrm{Co}$ and $\mathrm{Zn}$ bioaccumulation indicated that the protective role of the eggshell was element- and time-dependent, with the late developmental stages being more permeable to the elements, in particular to $\mathrm{Zn}$ and, to a lesser extent, Co. The selective penetration of these elements seems not being determined by their essential or non-essential nature. Indeed, previous studies showed that $\mathrm{Cd}$ behaved in a very similar way as observed here for Co (Lacoue-Labarthe et al., 2008a). Nevertheless, the intensity of the physiological needs of the embryo could explain that $\mathrm{Zn}$ was accumulated much more efficiently than Co. Eventually, the size of the atom could be partly involved in the element-specific accumulation pattern through the eggshell. Indeed, ${ }^{241} \mathrm{Am}$ has a longer atomic radius $(175 \mathrm{pm})$ than $\mathrm{Co}$ and $\mathrm{Zn}(135 \mathrm{pm})$.

Regarding Mn, uptake kinetics in the whole egg and in eggshell reached a steady-state equilibrium. The kinetics in the whole-egg was clearly driven by the kinetics in the eggshell and, during the last 10-20 d of the development, by the accumulation of $\mathrm{Mn}$ in the embryo (see Figs 2 and 4). At day 50, 7\% of the total Mn was detected in the embryo. As Mn is an essential co-factor for enzymes such as Mn-SOD or respiratory enzymes (Barceloux, 1999; Hernroth et al., 2004) its accumulation in the cuttlefish embryo could be linked with its predominantly aerobic respiration used to meet its energy requirements, especially after the first month of development (Wolf et al., 1985).

The eggshell binding capacity for Mn was rather limited as compared to Co, although it was expected that both elements would display a similar uptake pattern as they belong to the same chemical group (Adam et al., 2001). Mn depuration rate was quite similar regardless the duration of the exposure of the eggs to the dissolved element $(70 \pm 12$ to $89 \pm 3 \%$ of the Mn load of the egg was lost with a $\mathrm{Tb}_{1 / 2}$ ranging between $19 \pm 2$ and $29 \pm 19 \mathrm{~d}$ ). This suggests that $\mathrm{Mn}$ retention in the eggshell would not be affected by the eggshell polymerization and delaminating of its outer layers. This is supported by the fact that, during our experiments, we detected $\mathrm{Mn}$ in the eggshell inner layers (data not shown) that are originally secreted by the oviducal gland (Boletzky, 1986) and which location actually preserves from the influences described above. 
Finally, Cs uptake kinetics in the whole eggs were closely similar to the pattern of egg weight variation along the development time. It is well documented that cuttlefish egg weight varies mainly due to seawater inputs/outputs. Once spawning has occurred and eggs are in contact with seawater, the gelatinous eggshell begins to harden, with a concomitant loss of water, as the result of the polymerization of the eggshell mucopolysaccharidic compounds (Boletzky, 1998). The whole polymerization process takes about $10 \mathrm{~d}$, at which time the egg reached its minimal weight. When we placed the eggs in depuration conditions after a 7-d exposure, Cs was depurated according to a biexponential kinetics, which supported the hypothesis that, in the incompletely polymerized eggshell, part of the Cs would be trapped among the mucosubstances and released slowly $\left(T_{b^{1} / 2}=44 d\right)$ whereas part of it is slightly adsorbed and rapidly released $\left(\mathrm{T}_{\mathrm{b}^{1 / 2}}=0.3 \mathrm{~d}\right)$. Then, from $10 \mathrm{~d}$, the eggshell polymerization is completed as indicated by the minimal LCR value of Cs observed at this time. From the $20^{\text {th }}$ day of the embryo development, water intake in the peri-vitelline space induces an egg swelling (Gomi et al., 1986); this was similarly detected through a corresponding increase of the Cs accumulation. The mono-exponential depuration kinetics determined after a 18-d exposure corroborates the assumption that Cs was only bound to the hardened eggshell between the days 10 and 20, whereas the bi-exponential model determined after 27 and $40 \mathrm{~d}$ of exposure suggests that Cs was then taken up by the internal egg compartments. This was actually confirmed by the dissections that demonstrated that almost 20 and $27 \%$ of the total Cs load were distributed in the embryo and peri-vitelline fluid, respectively, after $33 \mathrm{~d}$ of development. Indeed, Cs is an analogue of potassium (Ke et al., 2000; Bustamante et al., 2006a), which could lead to its active accumulation in the growing embryo.

In summary, the eggshell acts as an efficient shield that protects the embryo against direct metal exposure at least during the first month of its development. This can be an important advantage for organisms living and reproducing in coastal waters that are often heavily contaminated by trace elements. Nevertheless, the eggshell shielding capacities appears to be profitably limited for essential 
elements such as $\mathrm{Co}, \mathrm{Mn}$ and $\mathrm{Zn}$ and for $\mathrm{Cs}$ due to increasing permeability from the $30^{\text {th }}$ day of development onwards.

Overall, the chemical properties of the contaminants do not seem sufficient to explain the differences in uptake patterns observed in this study. It is noteworthy that Cs accumulated in the embryo whereas it is the biggest atom (atomic radius: $260 \mathrm{pm}$ ). Therefore further studies should be carried out to assess the influence of physiological and/or biological processes in these contrasting accumulation behaviours during the embryo development. For example, the eggshell oviducal mucosubstances have a role in the formation of the peri-vitelline space in fertilized eggs of Todarodes pacificus (Ikeda et al., 1993). Indeed, Gomi et al. (1986) hypothesized that egg swelling would be due to transfer of organic matter from the eggshell to the peri-vitelline fluid via the chorion, which would result in an osmotic-driven water intake. This shows that a close relationship does exist between the embryo and the eggshell. Moreover, it is noteworthy that bacteria are transferred from the accessory nidamental gland to the eggshell where they might have a protective antimicrobial function (Barbieri et al., 1997). These symbiotic organisms could be also involved in trace element diffusion/retention mechanisms.

\section{Acknowledgments}

We are grateful to M. Metian (IAEA-MEL) for skilful assistance during the experiments. MW is an Honorary Senior Research Associate of the National Fund for Scientific Research (NFSR, Belgium) and holds a 2008 Invited Expert position at LIENSs (CNRS-Université de La Rochelle), supported by the Conseil Régional de Poitou-Charente. The IAEA is grateful for the support provided by the Government of the Principality of Monaco to its Marine Environment Laboratories. This work was supported by the IAEA and LIENSs. 


\section{References}

Adam, C., Baudin, J.P., Garnier-Laplace, J., 2001. Kinetics of ${ }^{110 m} \mathrm{Ag},{ }^{60} \mathrm{Co},{ }^{137} \mathrm{Cs}$ and ${ }^{54} \mathrm{Mn}$ bioaccumulation from water and depuration by the crustacean Daphnia magna. Water Air Soil Pollut. 125, 171-188.

Baden, S.P., Eriksson, S.P., Gerhardt, L., 1999. Accumulation and elimination kinetics of manganese from different tissues of the Norway lobster Nephrops norvegicus (L.). Aquat. Toxicol. 46, 127-137. Barbieri, E., Barry, K., Child, A., Wainwright, N., 1997. Antimicrobial activity in the microbial community of the accessory nidamental gland and egg cases of Loligo pealei (Cephalopoda: Loliginidae). Biol. Bull. 193, 275-276.

Barceloux, D., 1999. Manganese. J. Toxicol. Clin. Toxicol. 37, 293-307.

Boletzky, S.V., 1986. Encapsulation of cephalopod embryos: a search for functional correlations. Am. Malacol. Bull. 4, 217-227.

Boletzky, S.V., 1998. Cephalopod eggs and egg masses. Oceanogr. Mar. Biol. 36, 341-371.

Boucaud-Camou, E., Boismery, J., 1991. The migrations of the cuttlefish (Sepia officinalis L) in the English Channel. In: E. Boucaud-Camou (Ed.), The Cuttlefish. Centre de publication de l'Université de Caen, Caen, France.

Bustamante, P., Teyssié, J.L., Fowler, S.W., Cotret, O., Danis, B., Miramand, P., Warnau, M., 2002. Biokinetics of zinc and cadmium accumulation and depuration at different stages in the life cycle of the cuttlefish Sepia officinalis. Mar. Ecol. Prog. Ser. 231, 167-177.

Bustamante, P., Teyssié, J.L., Danis, B., Fowler, S.W., Miramand, P., Cotret, O., Warnau, M., 2004. Uptake, transfer and distribution of silver and cobalt in tissues of the common cuttlefish Sepia officinalis at different stages of its life cycle. Mar. Ecol. Prog. Ser. 269, 185-195. 
Bustamante, P., Teyssié, J.L., Fowler, S.W., Warnau, M., 2006a. Contrasting bioaccumulation and transport behaviour of two artificial radionulides $\left({ }^{241} \mathrm{Am}\right.$ and $\left.{ }^{134} \mathrm{Cs}\right)$ in cuttlefish eggshell. Vie Milieu $56,153-156$.

Bustamante, P., Teyssié, J.L., Fowler, S.W., Warnau, M., 2006b. Assessment of the exposure pathway in the uptake and distribution of americium and cesium in cuttlefish (Sepia officinalis) at different stages of its life cycle. J. Exp. Mar. Biol. Ecol. 331, 198-207.

Calabrese, A., Nelson, D.A., 1974. Inhibition of embryonic development of the hard clam Mercenaria mercenaria by heavy metals. Bull. Environ. Contam. Toxicol. 11, 92-97.

Coteur, G., Gosselin, P., Wantier, P., Chambost-Manciet, Y., Danis, B., Pernet, P., Warnau, M., Dubois, P., 2003. Echinoderms as bioindicators, bioassays, and impact assessment tools of sedimentassociated metals and PCBs in the North Sea. Arch. Environ. Contam. Toxicol. 45, 190-202.

Danis, B., Wantier, P., Flammang, R., Dutrieux, S., Dubois P., Warnau, M., 2004. Contaminant levels in sediment and asteroids (Asterias rubens, Echinoderm) from the Belgian coast and Scheldt estuary: polychlorinated biphenyls and metals. Sci. Total Environ. 333, 149-165.

De Leersnyder, M., Lemaire, J., 1972. Sur la composition minérale du liquide pérembryonnaire de l'œuf de Sepia officinalis L. Cah. Biol. Mar. 13, 429-431.

Falchuk, K.H., Montorzi, M., 2001. Zinc physiology and biochemistry in oocytes and embryos. Biometals 14, 385-395.

Gomi, F., Yamamoto, M., Nakazawa, T., 1986. Swelling of egg during development of the cuttlefish, Sepiella japonica. Zool. Sci. 3, 641-645.

Hernroth, B., Baden, S.P., Holm, K., André, T., Söderhäll, I 2004. Manganese induced immune suppression of the lobster Nephrops norvegicus. Aquat. Toxicol. 70, 223-231.

Ikeda, Y., Sakurai, Y., Shimazaki, K., 1993. Fertilizing capacity of squid (Todarodes pacificus) spermatozoa collected from various storage sites, with special reference to the role of gelatinous 
substance from the oviductal gland in fertilization and embryonic development. Invert. Reprod. Dev. 23, 39-44.

Jecklin, L., 1934. Beitrag zur kenntnis der laichgallertern und der biologie der embryonen decapoder cephalopoden. Rev. Suisse Zool. 41, 593-673.

Jeffree, R.A., Warnau, M., Teyssié, J.L., Markich, S.J., 2006. Comparison of the bioaccumulation from seawater and depuration of heavy metals and radionuclides in the spotted dogfish Scyliorhinus canicula (Chondrichthys) and the turbot Psetta maxima (Actinopterygii: Teleostei). Sci. Total Environ. 368, 839-852.

Ke, C., Yu, K.N., Lam, P.K.S., Wang, W.X., 2000. Uptake and depuration of cesium in the green mussel Perna viridis. Mar. Biol. 137, 567-575.

Kimura, S., Higuchi, Y., Aminaka, M., Bower, J.R., Sakurai, Y., 2004. Chemical properties of eggmucin complexes of the ommastrephid squid Todarodes pacificus. J. Mollusc. Stud. 70, 117-121.

Lacoue-Labarthe, T., Warnau, M., Oberhänsli, F., Teyssié, J.L., Kouéta, N., Bustamante, P., 2008a. Differential bioaccumulation behaviour of $\mathrm{Ag}$ and $\mathrm{Cd}$ during the early development of the cuttlefish Sepia officinalis. Aquat. Toxicol. 86, 437-446.

Lacoue-Labarthe, T., Warnau, M., Oberhänsli, F., Teyssié, J.L., Jeffree, R., Bustamante, P., 2008b. First experiments on the maternal transfer of metals in the cuttlefish Sepia officinalis. Mar. Pollut. Bull. 57, 826-831.

Lacoue-Labarthe T., Martin, S., Oberhänsli, F., Teyssié, J.L., Markich, S., Jeffree, R., Bustamante, P. (submitted) Effects of increased $\mathrm{pCO}_{2}$ and temperature on trace element $(\mathrm{Ag}, \mathrm{Cd}$ and $\mathrm{Zn}$ ) bioaccumulation in the eggs of the common cuttlefish, Sepia officinalis. Biogeosciences.

Miramand, P., Guary, J.C., 1981. Association of americium-241 with adenochromes in the branchial hearts of the cephalopod Octopus vulgaris. Mar. Ecol. Prog. Ser. 4, 127-129. 
Miramand, P., Germain, P., Trilles, J.P., 1989. Histo-autoradiographic localisation of americium $\left({ }^{241} \mathrm{Am}\right)$ in tissues of European lobster Homarus gammarus and edible crab Cancer pagurus after uptake from labelled sea water. Mar. Ecol. Prog. Ser. 52, 217-225.

Miramand, P., Bustamante, P., Bentley, D., Kouéta, N., 2006. Variation of heavy metal concentrations ( $\mathrm{Ag}, \mathrm{Cd}, \mathrm{Co}, \mathrm{Cu}, \mathrm{Fe}, \mathrm{Pb}, \mathrm{V}$, and $\mathrm{Zn}$ ) during the life cycle of the common cuttlefish Sepia officinalis. Sci. Total Environ. 361, 132-143.

Nakahara, M., Koyanagi, T., Ueda, T., Shimizu, C., 1979. Peculiar accumulation of cobalt-60 by the branchial hearts of Octopus. Bull. Jap. Soc. Fish. Oceanogr. 45, 539.

Passow, U., 2002. Transparent exopolymer particles (TEP) in aquatic environments. Prog. Oceanogr. $55,287-333$.

Paulij, W.P., Zurburg, W., Denuce, J.M., Van Hannen, E.J., 1990. The effect of copper on the embryonic development and hatching of Sepia officinalis L. Arch. Environ. Contam. Toxicol. 19, 797-801.

Rodriguez y Baena, A.M., Boudjenoun, R., Fowler, S.W., Miquel, J.C., Masque, P., Sanchez-Cabeza, J.A., Warnau, M., 2008a. ${ }^{234}$ Th-based carbon export during an ice-edge bloom: sea-ice algae as a likely bias in data interpretation. Earth Planet. Sci. Lett. 269, 595-603.

Rodriguez y Baena, A.M., Fowler, S.W., Warnau, M., 2008b. Could krill schools significantly bias ${ }^{234}$ Th-based flux models? Limnol. Oceanogr. 53, 1186-1191.

Rodriguez y Baena, A.M., Metian, M., Teyssié, J.L., De Broyer, C., Warnau, M., $2006 a$. Experimental evidence for ${ }^{234} \mathrm{Th}$ bioaccumulation in three Antarctic crustaceans: Potential implications for particle flux studies. Mar. Chem. 100, 354-365.

Rodriguez y Baena, A.M., Miquel, J.C., Masqué, P., Povinec, P.P., La Rosa, J., 2006b. A single vs. double spike approach to improve the accuracy of ${ }^{234} \mathrm{Th}$ measurements in small-volume seawater samples. Mar. Chem. 100, 269-281. 
Temara, A., Warnau, M., Dubois, P., Langston, W.J., 1997. Quantification of metallothioneins in the common asteroid Asterias rubens (Echinodermata) exposed experimentally or naturally to cadmium. Aquat. Toxicol. 38, 17-34.

Vallee, B.L., Auld, D.S., 1990. Zinc coordination, function and structure of zinc enzymes and other proteins. Biochemistry 29, 5647-5659.

Villanueva, R., Bustamante, P., 2006. Composition in essential and non-essential elements of early stages of cephalopods and dietary effects on the elemental profiles of Octopus vulgaris paralarvae. Aquaculture 261, 225-240.

Warnau, M., Bustamante, P., 2007. Radiotracer techniques: a unique tool in marine ecotoxicological studies. Environ. Bioindictors 2, 217-218.

Warnau, M., Teyssié, J.L., Fowler, S.W., 1996a. Biokinetics of selected heavy metals and radionuclides in the common Mediterranean echinoid Paracentrotus lividus: sea water and food exposures. Mar. Ecol. Prog. Ser. 141, 83-94.

Warnau, M., Teyssié, J.L., Fowler, S.W., 1996b. Biokinetics of selected heavy metals and radionuclides in two marine macrophytes: the seagrass Posidonia oceanica and the alga Caulerpa taxifolia. Mar. Environ. Res. 41, 343-362.

Warnau, M., Iaccarino, M., De Biase, A., Temara, A., Jangoux, M., Dubois, P., Pagano, G 1996c. Spermiotoxicity and embryotoxicity of heavy metals in the echinoid Paracentrotus lividus. Environ. Toxicol. Chem. 15, 1931-1936.

Warnau, M., Fowler, S.W., Teyssié, J.L., 1999. Biokinetics of radiocobalt in the asteroid Asterias rubens (Echinodermata): sea water and food exposures. Mar. Pollut. Bull. 39, 159-164.

Wedemeyer, G., 1968. Uptake and distribution of ${ }^{65} \mathrm{Zn}$ in the coho salmon egg (Oncorhynchus kisutch). Comp. Biochem. Physiol. 26, 271-279.

Whicker, F.W., Schultz, V., 1982. Radioecology: nuclear energy and the environment, Vol 2. CRC Press, Boca Raton, FL. 
Wolf, G., Verheyen, E., Vlaeminck, A., Lemaire, J., Decleir, W., 1985. Respiration of Sepia officinalis during the embryonic and early juvenile life. Mar. Biol. 90, 35-39. 


\section{Captions to Figures}

Fig. 1. Sepia officinalis. Variation of the cuttlefish egg weight (g; mean $\pm \mathrm{SE}, \mathrm{n}=8$ ) along the duration of the development.

Fig. 2. Sepia officinalis. Uptake kinetics of ${ }^{241} \mathrm{Am},{ }^{57} \mathrm{Co},{ }^{54} \mathrm{Mn}$ and ${ }^{65} \mathrm{Zn}$ in cuttlefish whole eggs exposed for the entire development time to the radiotracers dissolved in seawater (load-concentration ratio, $\mathrm{LCR}(\mathrm{g})$; mean $\pm \mathrm{SE}, \mathrm{n}=8)$.

Fig. 3. Sepia officinalis. (A) Uptake kinetics of ${ }^{134} \mathrm{Cs}$ in cuttlefish whole eggs exposed for the entire development time to the radiotracer dissolved in seawater (load-concentration ratio, LCR (g); mean \pm SE, $n=8$ ) and (B) relationships between the LCR (g) of ${ }^{134} \mathrm{Cs}$ in the whole egg and the egg wet wt (g) from day 1 to 43 of the embryo development (Pearson correlation test).

Fig. 4. Sepia officinalis. Uptake kinetics of ${ }^{241} \mathrm{Am},{ }^{57} \mathrm{Co},{ }^{54} \mathrm{Mn}$ and ${ }^{65} \mathrm{Zn}$ in cuttlefish eggshell (o) and embryo $(\bullet)$ exposed for the whole development time to the radiotracers dissolved in seawater (loadconcentration ratio, $\mathrm{LCR}, \mathrm{g}$; mean $\pm \mathrm{SE}, \mathrm{n}=4$ ). 


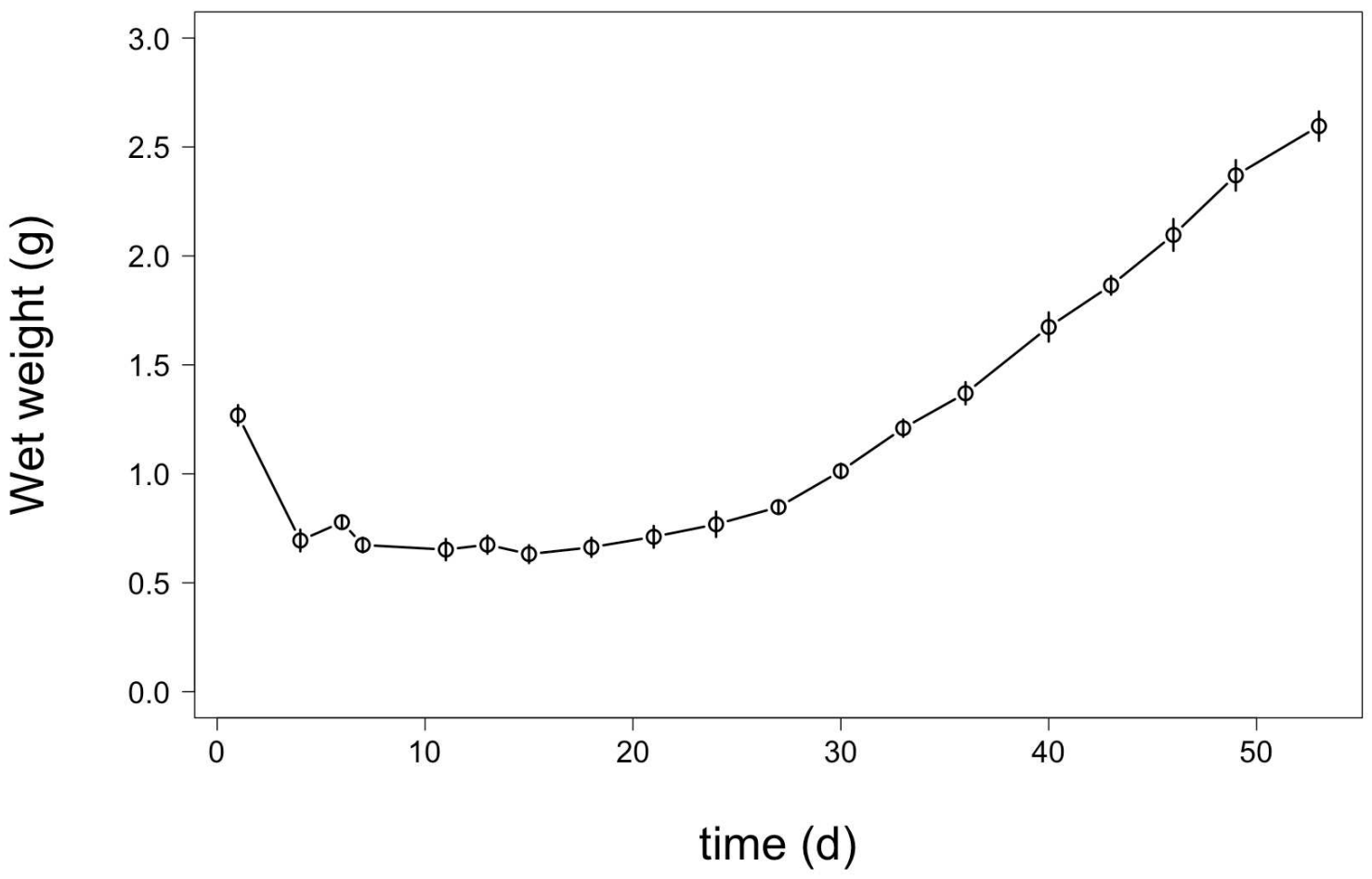

Figure 1. 

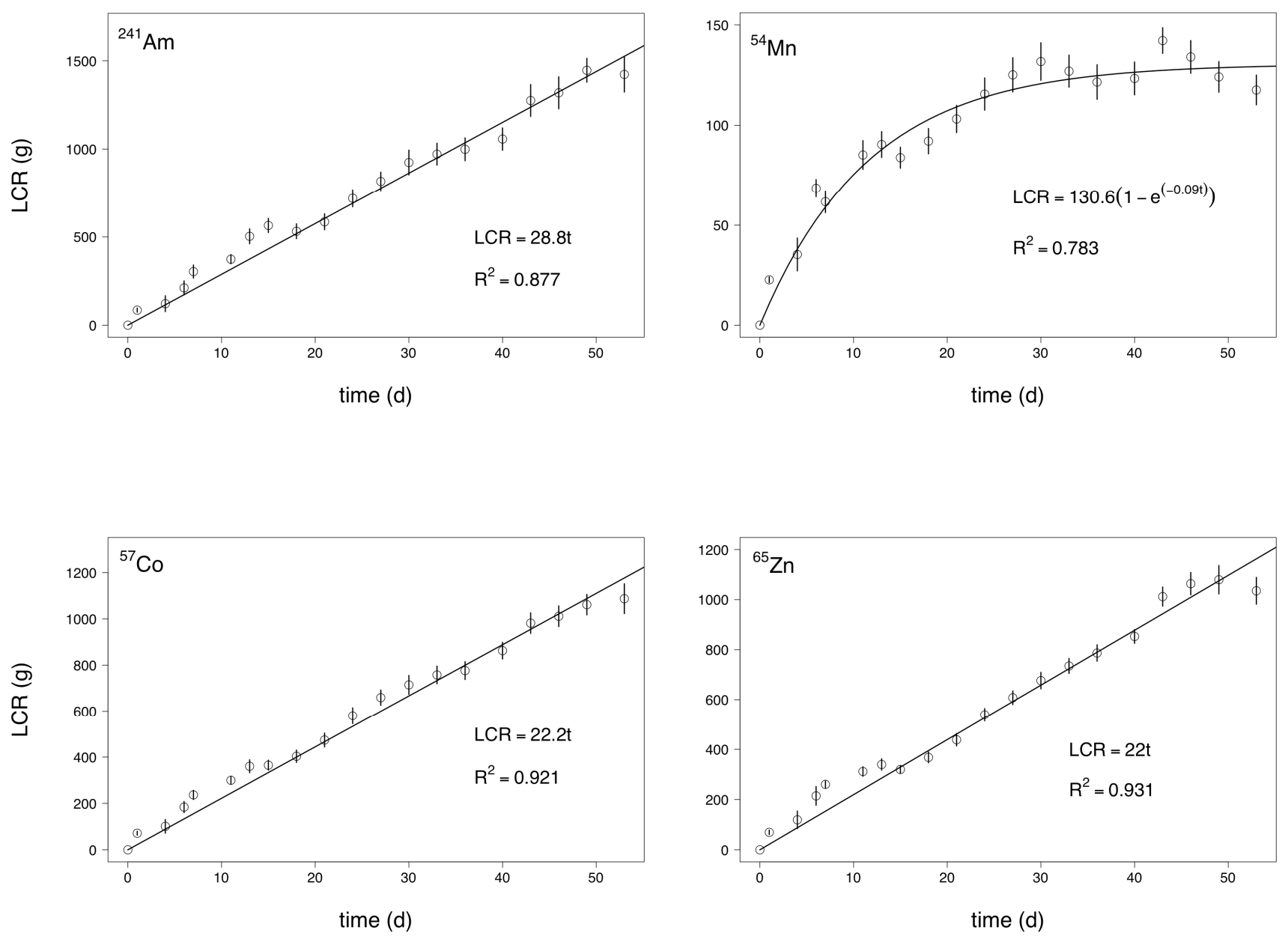

Figure 2. 

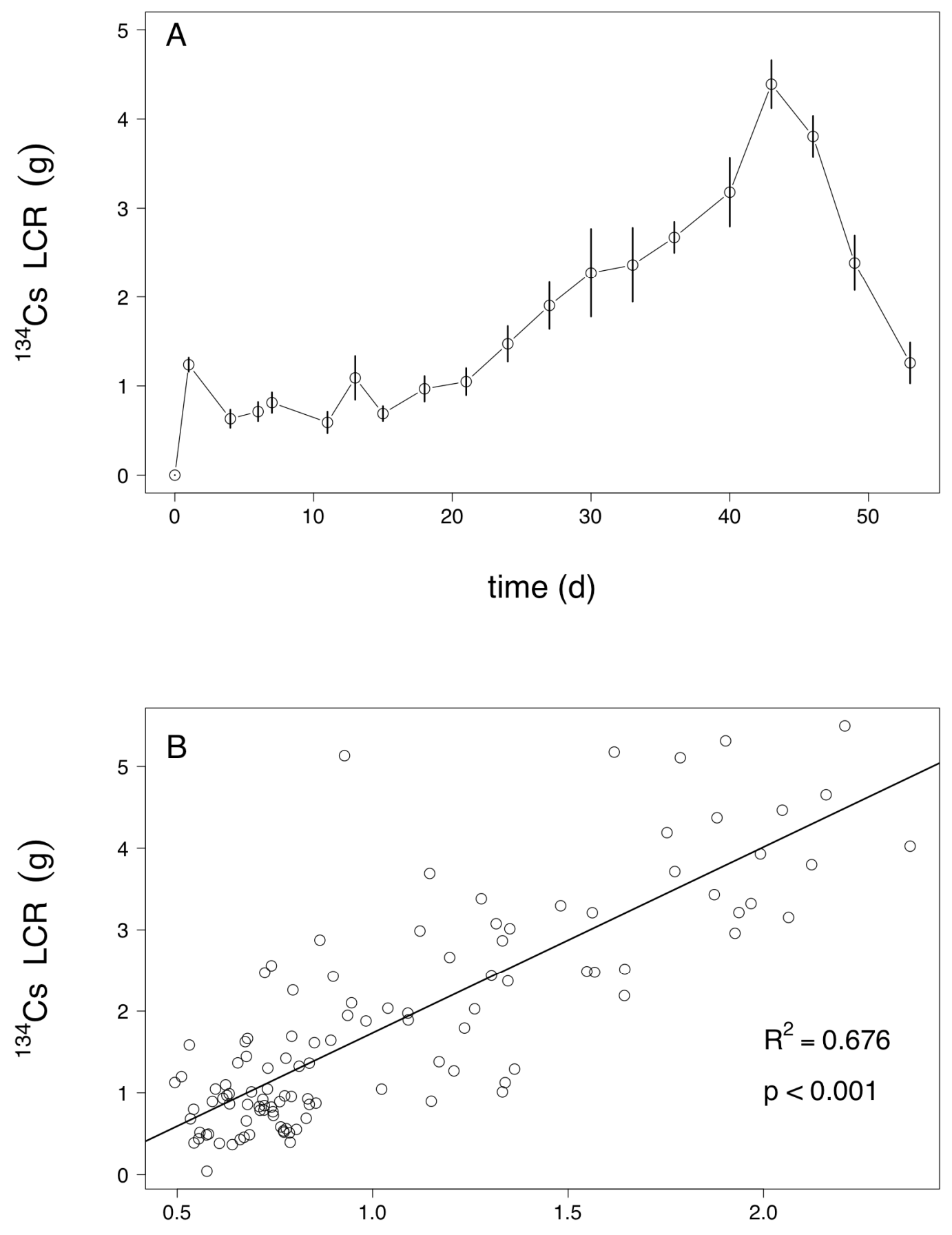

Egg wet weight (g)

Figure 3. 

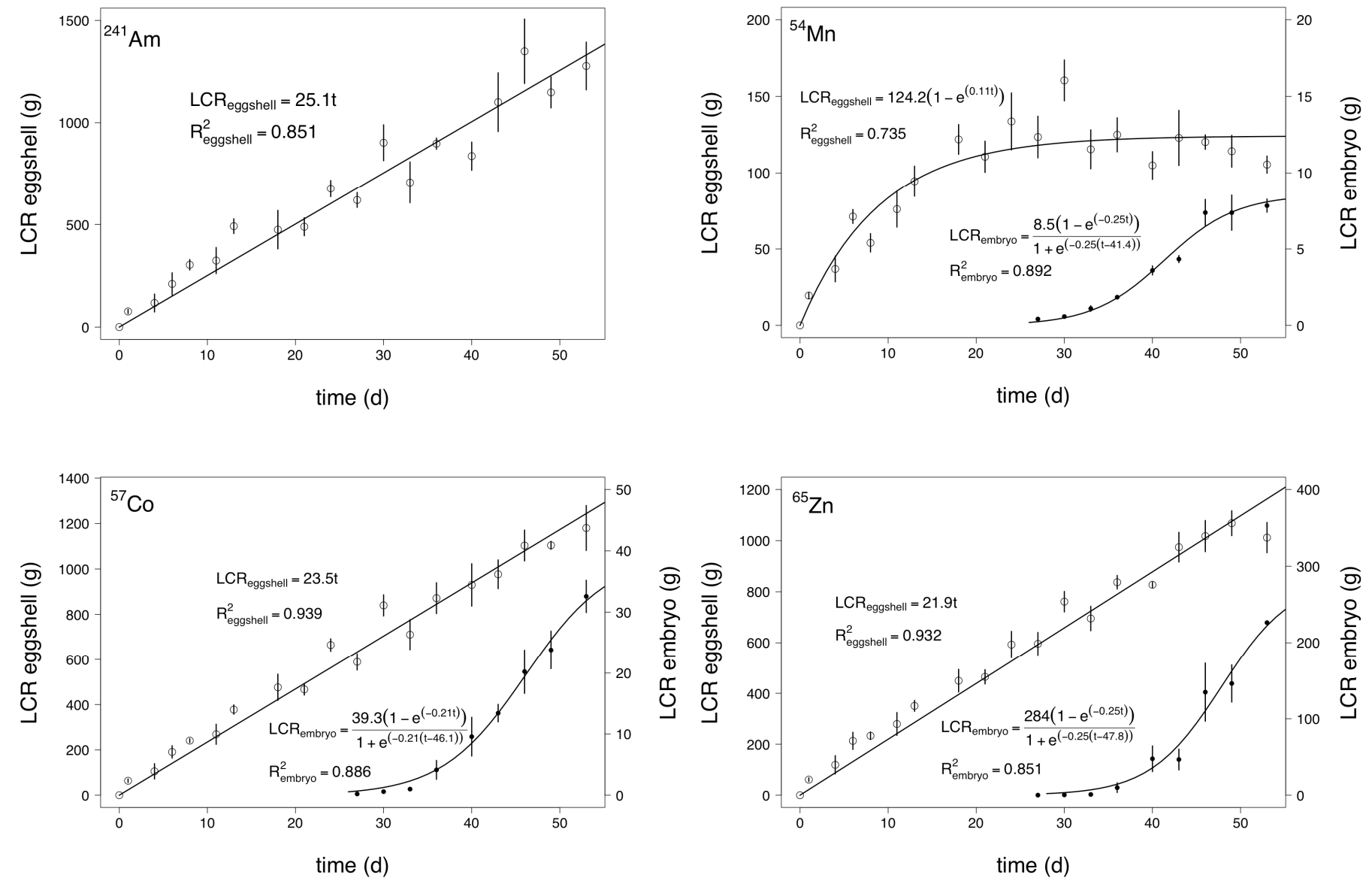

Figure 4. 
Table 1. Sepia officinalis. Distribution of the radiotracers (\%; mean \pm SD; $n=4)$ among cuttlefish egg compartments after 11, 33 and $50 \mathrm{~d}$ of exposure via seawater. The lack of peri-vitelline fluid and embryo at $11 \mathrm{~d}$ and of vitellus at $50 \mathrm{~d}$ did not allow determining distributions in these compartments at these sampling times.

\begin{tabular}{|c|c|c|c|c|c|c|c|c|c|}
\hline & \multicolumn{3}{|c|}{ Eggshell } & \multicolumn{2}{|c|}{ Vitellus } & \multicolumn{2}{|c|}{ Embryo } & \multicolumn{2}{|c|}{ Peri-vitellin fluid } \\
\hline & $11 \mathrm{~d}$ & $33 \mathrm{~d}$ & $50 \mathrm{~d}$ & $11 \mathrm{~d}$ & $33 \mathrm{~d}$ & $33 \mathrm{~d}$ & $50 \mathrm{~d}$ & $33 \mathrm{~d}$ & $50 \mathrm{~d}$ \\
\hline${ }^{241} \mathrm{Am}$ & $99.3 \pm 0.5$ & $99.5 \pm 0.1$ & $99.2 \pm 0.2$ & $<1$ & $<1$ & $<1$ & $<1$ & $<1$ & $<1$ \\
\hline${ }^{57} \mathrm{Co}$ & $99.7 \pm 0.0$ & $99.7 \pm 0.0$ & $97.0 \pm 0.3$ & $<1$ & $<1$ & $<1$ & $2.7 \pm 0.3$ & $<1$ & $<1$ \\
\hline${ }^{134} \mathrm{Cs}$ & $96.2 \pm 1.4$ & $50.7 \pm 9.2$ & $48.0 \pm 4.0$ & $3.8 \pm 1.4$ & $2.3 \pm 0.8$ & $19.9 \pm 2.1$ & $39.7 \pm 2.3$ & $27.2 \pm 7.1$ & $12.3 \pm 3.6$ \\
\hline${ }^{54} \mathrm{Mn}$ & $97.7 \pm 1.2$ & $98.0 \pm 0.3$ & $92.2 \pm 0.2$ & $2.3 \pm 1.2$ & $<1$ & $1.0 \pm 0.1$ & $6.9 \pm 0.2$ & $1.0 \pm 0.2$ & $1.0 \pm 0.1$ \\
\hline${ }^{65} \mathrm{Zn}$ & $99.9 \pm 0.0$ & $99.8 \pm 0.1$ & $81.2 \pm 1.1$ & $<1$ & $<1$ & $<1$ & $18.4 \pm 1.0$ & $<1$ & $<1$ \\
\hline
\end{tabular}


Table 2. Parameters of the equations describing the depuration kinetics of ${ }^{241} \mathrm{Am},{ }^{57} \mathrm{Co},{ }^{134} \mathrm{Cs},{ }^{54} \mathrm{Mn}$ and ${ }^{65} \mathrm{Zn}$ in the whole cuttlefish eggs previously exposed to the radiotracers for (a) $7 \mathrm{~d}$, (b) $18 \mathrm{~d}$, (c) $27 \mathrm{~d}$, and (d) $40 \mathrm{~d}$; $\mathrm{n}=8$ for each condition.

\begin{tabular}{|c|c|c|c|c|c|c|c|c|}
\hline Metal & Model & $\mathrm{A}_{0 \mathrm{~s}} \pm \mathrm{SE}$ & $\mathrm{k}_{\mathrm{es}}$ & $\mathrm{T}_{\mathrm{b}^{1 / 2 \mathrm{~s}}} \pm$ & $\mathrm{A}_{01} \pm \mathrm{SE}$ & $\mathrm{k}_{\mathrm{el}}$ & $\mathrm{T}_{\mathrm{b}^{1 / 2} / 2} \pm$ & $\mathrm{R}^{2}$ \\
\hline \multicolumn{9}{|c|}{ (a) Depuration in whole eggs after $7 \mathrm{~d}$ of exposure } \\
\hline${ }^{241} \mathrm{Am}$ & $\mathrm{O}$ & $98.2 \pm$ & 0.012 & $57 \pm 6$ & - & - & - & 0.881 \\
\hline${ }^{57} \mathrm{Co}$ & $\mathrm{O}$ & $91.8 \pm$ & 0.023 & $31 \pm 2$ & - & - & - & 0.950 \\
\hline${ }^{134} \mathrm{Cs}$ & $\mathrm{T}$ & $43.9 \pm$ & $2.495^{\mathrm{ns}}$ & $0.3 \pm 0.1$ & $56.3 \pm$ & 0.016 & $44 \pm 11$ & 0.882 \\
\hline${ }^{54} \mathrm{Mn}$ & $\mathrm{O}$ & $88.5 \pm$ & 0.036 & $19 \pm 2$ & - & - & - & 0.949 \\
\hline${ }^{65} \mathrm{Zn}$ & $\mathrm{T}$ & $37.3 \pm$ & $0.138^{\mathrm{ns}}$ & $5.0 \pm 2.3$ & $59.0 \pm$ & $0.006^{\mathrm{ns}}$ & $123 \pm 11$ & 0.960 \\
\hline
\end{tabular}

(b) Depuration in whole eggs after $18 \mathrm{~d}$ of exposure

$\begin{array}{rllllcccc}{ }^{241} \mathrm{Am} & \mathrm{O} & 95.9 \pm & 0.018 & 39 \pm 2 & - & - & - & 0.818 \\ { }^{57} \mathrm{Co} & \mathrm{O} & 94.8 \pm & 0.021 & 33 \pm 2 & - & & - & 0.797 \\ { }^{134} \mathrm{Cs} & \mathrm{O} & 82.1 \pm & 0.024 & 29 \pm 8 & - & - & - & 0.192 \\ { }^{54} \mathrm{Mn} & \mathrm{T} & 13.1 \pm & 0.887 * & 0.8 \pm 0.4 & 87.2 \pm & 0.029 & 24 \pm 1 & 0.936 \\ { }^{65} \mathrm{Zn} & \mathrm{T} & 21.2 \pm & 0.806 & 0.9 \pm 0.2 & 79.0 \pm & 0.014 & 50 \pm 5 & 0.871\end{array}$

(c) Depuration in whole eggs after $27 \mathrm{~d}$ of exposure

$\begin{array}{ccclccccc}{ }^{241} \mathrm{Am} & \mathrm{T} & 8.3 \pm 2.9 & 0.610^{\mathrm{ns}} & 1.1 \pm 0.8 & 91.8 \pm & 0.022 & 32 \pm 3 & 0.926 \\ { }^{57} \mathrm{Co} & \mathrm{O} & 98.3 \pm & 0.030 & 24 \pm 1 & - & - & - & 0.855 \\ { }^{134} \mathrm{Cs} & \mathrm{T} & 55.9 \pm & 0.266^{\mathrm{ns}} & 2.6 \pm 2.1 & 31.6 \pm & 0.007 & 98 \pm 603 & 0.428 \\ { }^{54} \mathrm{Mn} & \mathrm{T} & 17.6 \pm & 0.751 & 0.9 \pm 0.3 & 82.7 \pm & 0.033 & 21 \pm 1 & 0.857 \\ { }^{65} \mathrm{Zn} & \mathrm{T} & 26.3 \pm & 0.180 & 0.8 \pm 0.2 & 73.6 \pm & 0.015 & 46 \pm 5 & 0.921\end{array}$

(d) Depuration in whole eggs after $40 \mathrm{~d}$ of exposure

$\begin{array}{ccccccccc}{ }^{241} \mathrm{Am} & \mathrm{O} & 98.3 \pm & 0.040 & 18 \pm 2 & - & - & - & 0.714 \\ { }^{57} \mathrm{Co} & \mathrm{O} & 96.8 \pm & 0.030 & 24 \pm 1 & - & - & - & 0.870 \\ { }^{134} \mathrm{Cs} & \mathrm{T} & 67.2 \pm & 1.373 & 0.5 \pm 0.2 & 32.8 \pm & 0.030^{\mathrm{ns}} & 23 \pm 37 & 0.831 \\ { }^{54} \mathrm{Mn} & \mathrm{T} & 30.1 \pm & 0.504^{\mathrm{ns}} & 1.4 \pm 0.8 & 70.2 \pm & 0.024^{\mathrm{ns}} & 29 \pm 19 & 0.891 \\ { }^{65} \mathrm{Zn} & \mathrm{T} & 33.3 \pm & 0.691 & 1.0 \pm 0.4 & 66.8 \pm & 0.009^{\mathrm{ns}} & 79 \pm 100 & 0.851\end{array}$

$\mathrm{O}$ and T: 1- and 2-component exponential models, respectively; $\mathrm{A}_{0 \mathrm{~s}}$ and $\mathrm{A}_{01}$ : assimilation efficiency of the short- and long-lived component, respectively; SE: standard error; R2: determination coefficient; p-values: $<0.001(* * *),<0.01(* *),<0.05(*),>0.5$ (ns). 